\title{
RESEPSI PEMBACA TERHADAP UNSUR FAKTA CERITA DALAM NOVEL AYAT AYAT CINTA KARYA HABIBURRAHMAN EL- SHYRAZI
}

\author{
Munaris \\ Fakultas Keguruan dan Ilmu Pendidikan Universitas Lampung \\ email: munaris_labib@yahoo.co.id
}

\begin{abstract}
This study aims to describe readers' reception of story fact elements (character, plot, and setting) in Ayat-Ayat Cinta (AAC). The data sources were reception texts uploaded by readers and were downloaded through Google. The data analysis and interpretation employed a combination of two perspectives, i.e. text reception and hermeneutics. The findings show that readers respond to the elements in the reception with positive and negative tones. In general, however, they respond to the elements positively. The characters that most readers respond to are Fahri, Aisha, Maria, and Nurul. Readers respond to the plot of AAC holistically, but most of them respond to only parts of the plot. They respond to two settings, i.e. spatial and social settings.
\end{abstract}

Keywords: readers' reception, story fact, hermeneutics

\section{PENDAHULUAN}

Afrizal Malna dalam lembar ucapan terima kasih atas penerbitan bukunya yang berjudul Sesuatu Indonesia pada awal paragraf menyatakan sebagai berikut.

Banyak hal yang membuat buku ini bisa terbit. Banyak cerita juga di balik penerbitannya, yang membuat saya terheran-heran dan akhirnya seperti harus percaya bahwa buku seperti anak yang akhirnya harus menempuh hidupnya sendiri. Terpisah dari ayah penulisnya (Malna, 2000: ix).

Dari pernyataan tersebut, dapat ditafsirkan bahwa untuk mewujudkan teks buku yang setelah dicetak setebal 580 halaman, Malna melalui berbagai proses.Secara global proses tersebut meliputi baik proses pada diri si penulis dan proses pencetakan dan penerbitan. Penuangkan segala sesuatu dalam bentuk tulisan merupakan pembakuan segala sesuatu dalam wujud teks. Hal tersebut sesuai dengan pendapat Ricoeur (Valdes (Ed.), 1991: 43-45) dan Ricoeur, 1981: 196-197) mengenai teks, yaitu teks adalah setiap wacana yang dibakukan dalam tulisan. Pembakuan dalam tulisan merupakan ciri teks. Namun, sebuah teks benar-benar menjadi teks ketika ia langsung membubuhkan yang dimaksud wacana ke dalam tulisan.

Teks yang telah dihasilkan oleh Malna merupakan teks yang mandiri sehingga penulis menyatakan yang membuat saya terheran-heran dan akhirnya seperti harus percaya bahwa buku seperti anak yang akhirnya harus menempuh hidupnya sendiri. Terpisah dari ayah penulisnya. Meskipun mengherankan, hal tersebut tetap harus terjadi karena penulis tidak mungkin mengekang teks yang telah di lepaskan untuk tunduk pada kemauan penulis, misalnya berkaitan dengan penafsiran/pemaknaan teks. Bahkan, jika penulisnya membaca teks yang ditulisnya, sesungguhnya penulis tersebut 
telah beralih posisi dari penulis menjadi pembaca yang memungkinkan menafsirkan dan memaknai teks tersebut secara berbeda dengan ketika menulis.

Pembaca, siapa pun dia, memunyai otonomi untuk memaknai teks karena penafsiran dan pemaknaan merupakan hasil dialogis antara pembaca dan teks walaupun kadang-kadang pembaca masih mempertimbangkan keberadaan penulisnya, namun makna tetap milik pembaca. Dengan kata lain, jika pemaknaan terhadap teks bergantung pada makna dari penulis yang membaca, makna tersebut sesungguhnya juga merupakan penafsiran pembaca yang juga merupakan preface untuk penafsiran-penafsiran berikutnya karena, menurut Derrida, penafsiran tidak pernah berhenti (Aminuddin, 2002:155).

Teks harus hidup mandiri dan terlepas dari penulisnya. Roland Barthes menyatakan the author is dead (anonimitas). Strategi pemahaman terhadap karya seni dengan menganggap subjek pencipta sudah anonim (mati). Tujuannya untuk memberikan kebebasan terhadap ruang penikmat dalam memberikan penilaian. Karya sastra adalah sesuatu yang telah dikatakan oleh pengarang (Ratna, 2007: 444)

Bersamaan dengan matinya penulis, hiduplah pembaca. Teks telah memiliki penjarakan. Teks telah melepaskan dirinya dari konteks sosial dan sejarah penciptaan dan membuka dirinya bagi berbagai pembacaan tanpa batas Ricoeur (1981: 19). Derrida, seperti yang dikutip oleh Gunawan Mohamad, menyatakan sebagai berikut.

Bila seseorang menulis sebuah buku untuk pembaca yang luas, ia tak tahu kepada siapa ia bicara, orang akan membentuk dan menciptakan garis besarnya, tapi semua itu tak lagi milik kita. Diucapkan atau dituliskan, semua gerak (gestes) yang mencoba memberi tahu itu meninggalkan kita: mereka bertindak mandiri dari kita, seperti mesin, atau, yang terbaik, seperti boneka.... Pada saat saya mengizinkan buku saya diterbitkan ... saya mulai muncul-dan-lenyap, seakan-akan sejenis hantu yang tak dapat disentuh yang tak pernah belajar bagaimana hidup. Jejak yang saya tinggalkan menandai kematian saya, nanti ataupun di masa lalu, tapi juga menandai harapan bahwa jejak itu akan hidup-terus setelah saya. Ini bukan ambisi untuk hidup kekal, ini struktural (dalam Al-Fayyadl, 2005:xii).

Berkaitan dengan keberadaan $A A C$ yang merupakan cerita naratif yang telah dibukukan, $A A C$ juga memiliki ciri penjarakan. Pembaca memiliki kebebasan menafsirkan dan meresepsi $A A C$. Pembaca menafsirkan dan memaknai teks tidak lagi bergantung pada penulis $A A C$, tetapi pembaca berinteraksi dengan teks. Sartre (1967:53) menyatakan sebentar kemudian kusadari buku itu yang berbicara.

Sebentar kemudian kusadari buku itu yang berbicara. Kalimat-kalimat muncul yang menakutkanku. Semua nyata seperti lipan. Semua berbondong-bondong dengan suku kata dan huruf-huruf, memperpanjang diftong dan menggandakan konsonan dengan seruling, bunyi sengau ditingkahi dengusan dan pause. Kaya dalam kata-kata tak dikenal, semua itu jatuh cinta pada diri sendiri dan kelok-kelok mereka dan tak punya waktu untukku. Kadang-kadang mereka menghilang sebelum aku bisa memahami. Lain-lainnya sudah kumengerti dan mereka berputar anggun menuju akhir tanpa memberiku koma. Kata-kata ini jelas tak dimaksudkan bagiku. Kisah itu sendiri ada pada pakaian yang terbagus: pemotong kayu, istri pemotong kayu dan 
putrid mereka, peri, orang-otang liliput, sesama makhluk, memiliki keagungan. Pakaian compang-camping mereka digambarkan dengan menakjudkan. Kata-kata meninggalkan tanda mereka pada objek-objek, mengubah aksi menjadi ritual dan peristiwa menjadi seremoni.

Pernyataan Satre tersebut berkaitan dengan interaksinya ketika membaca sebuah cerita. Menurut Sayuti (2006:2), Iser menggambarkan komunikasi sastra sebagai aktivitas gabungan pembaca dan teks, yang masing-masing bertindak "bergantung satu sama yang lain dalam suatu proses yang mengatur dirinya sendiri (self-regulating process). Dengan demikian, teks memunyai daya hidup dan dihidupkan dalam imajinasi pembaca yang pada akhirnya pembaca dapat menafsirkan dan memaknai teks.

Untuk dapat menafsirkan dan memaknai teks, pembaca tentu harus memunyai, apapun itu, bahan dasar yang menunjang untuk proses tersebut, baik sebagai makluk individu, sosial, dan ideologis. Persamaan dan perbedaan yang dimiliki oleh pembaca menimbulkan persamaan atau perbedaan penafsiran dan pemaknaan terhadap teks yang berimplikasi juga pada persamaan atau perbedaan dalam meresepsi $A A C$. Dalam konteks tersebut dikenal juga adanya istilah horizon harapan pembaca. Menurut Ratna (2007), horison harapan (erwartungshorizont) adalah citra, cakrawala, harapan pembaca yang berubah secara terus-menerus, timbul sebagai akibat pembacaan terdahulu.

Selain adanya horizon harapan, perbedaan dan persamaan juga disebabkan novel $A A C$ merupakan teks yang memunyai sifat multitafsir karena adanya ruang kosong dalam teks tersebut. Ruang kosong merupakan kondisi tekstual yang memungkinkan dimaknai dan dikonkretkan secara sama atau se- cara berbeda. Ingarden dalam Holub (1984) menjelaskan bahwa objek-objek karya sastra merepresentasikan bercakbercak atau poin-poin atau tempat-tempat yang belum tentu (indeterminacy). Perpaduan antara horizon harapan dan ruang kosong dalam proses pembacaan/peresepsian dapat dicermati pada pernyataan Rosenblatt (1978), yaitu yang dibawa pembaca ke dalam teks akan memengaruhi yang pembaca ciptakan dari petunjuk-petunjuk verbal. Iser (1987) menyatakan bahwa pusat pembacaan tiap karya sastra adalah interaksi antara strukturnya dan penerimanya. Inilah mengapa teori fenomenologis seni dengan tegas memberi perhatsian pada fakta bahwa penelitian terhadap karya sastra harus memperhatikan bukan hanya teksnya tetapi juga, dalam ukuran yang sama, tindakan yang terlibat dalam merespon teks tersebut.

\section{METODE}

Ancangan penelitian yang digunakan adalah ancangan hermeneutik. Dengan ancangan tersebut sentral kegiatan penelitian adalah kerja interpretasi/ penafsiran, yaitu penafsiran terhadap teks resepsi yang diproduksi pembaca $A A C$. Teks resepsi pembaca dipandang otonom sehingga dalam menafsirkan teks tersebut peneliti tidak mempertimbangkan keberadaan penulis teks resepsi. Namun, untuk memberikan konteks pada teks resepsi, peneliti mempertimbangkan keberadaan teks AAC. Alur kerja interpretasi yang digunakan adalah alur kerja menurut Ricoeur (1981: 286), yaitu beranjak dari pemahaman (verstehen) ke penjelasan (erklaren).

Ruang lingkup penelitian ini ada pada wilayah kajian tersepsi pembaca terhadap teks. Dalam hal ini teks yang diresepsi adalah teks sastra.Oleh karena itu, fokus kajian ada wilayah resepsi pembaca, khususnya resepsi pembaca terhadap $A A C$. Resepsi yang dimaksud 
adalah resepsi produktif, yaitu resepsi yang diaktulisasikan dalam tulisan/ teks.

Data penelitian dikumpulkan dari teks (sumber data) yang berupa resepsi pembaca yang diunggah di internet. Cara yang digunakan untuk mengakses sumber data adalah dengan memasukkan kata akses "tanggapan pembaca novel ayat ayat cinta" pada program searching Google.

Kajian difokuskan pada tiga hal, yaitu (1) resepsi pembaca terhadap tokoh-tokoh $A A C$, (2) resepsi pembaca terhadap alur $A A C$, dan (3) resepsi pembaca terhadap latar $A A C$. Untuk mengungkapkan ketiga fokus tersebut digunakan perpaduan dua perspektif, yaitu resepsi terhadap teks dan hermeneutika. Resepsi teks digunakan sebagai dasar teoretis untuk menemukan/menentukan ontologi kajian resepsi yang berfokus pada pembaca. Perspektif hermeneutika digunakan sebagai dasar epistemologi untuk memahami dan menjelaskan proses penafsiran, terutama penafsiran peneliti terhadap teks yang meliputi dua kategori teks, yaitu teks resepsi (utama) dan teks $A A C$ (teks sebagai konteks teks utama), namun juga dipertimbangkan teksteks lain yang relevan.

Teknik interpretasi terhadap teks resepsi dan teks novel $A A C$ untuk memperoleh interpretasi yang memadai (sesuai dengan tujuan penelitian), digunakan teknik lingkaran hermeneutis. Ibrahim (2007:11) menjelaskan bahwa seorang interpreter memandang suatu teks khusus berdasarkan gagasan umum tentang apa yang mungkin dimaksudkan teks itu, kemudian memodifikasi ide umum itu berdasar pemeriksaan terhadap ciri-ciri khusus teks. Selanjutnya, dalam putaran hermeneutika itu selalu menghubungkan apa yang dilihat dalam objek itu dengan apa yang diketahui. Interpreter kemudian bergantian beralih antara seperangkat konsep yang dikenal dengan yang tak dikenal sampai keduanya menyatu dalam suatu interpretasi tentatif.

\section{HASIL DAN PEMBAHASAN}

Dalam terminilogi Stanton (1965) unsur cerita seperti tokoh, alur dan latar termasuk dalam kategori fakta cerita. Berikut ini dikemukakan mengenai resepsi pembaca terhadap tiga unsur tersebut.

\section{Resepsi Pembaca terhadap Tokoh $A A C$}

Mengenai tokoh, Aminuddin (2009:79) menyatakan tokoh adalah pelaku yang mengemban peristiwa dalam cerita fiksi sehingga peristiwa itu mampu menjalin suatu cerita. Deskripsi dan penjelasan resepsi pembaca terhadap tokoh dibatasi pada empat tokoh, yaitu Fahri, Aisha, Maria, dan Nurul. Pembatasan tersebut didasarkan pada data yang ada, yaitu kutipan dari teks resepsi yang merepresentasikan resepsi pembaca terhadap tokoh $A A C$.

Dari keempat tokoh tersebut, Fahri adalah tokoh yang paling banyak diresepsi oleh pembaca, yaitu ditemukan 93 resepsi pembaca terhadap Fahri. Fahri sebagai tokoh utama dikenalkan kepada pembaca melalui rangkaian kegiatan sehari-hari, baik kegiatannya sebagai anggota masyarakat di lingkungan tempat tinggal, sebagai mahasiswa S2 di Al Azhar, sebagai murid mengaji dari Syaikh yang sangat terkenal, sebagai penceramah (pengotbah), maupun aktivitas yang lainnya. Fahri begitu hidup dalam diri pembaca, bahkan pembaca seolah-olah menjadi Fahri dalam novel ini.

Resepsi yang demikian banyak terhadap Fahri merupakan sesuatu yang logis karena porsi Fahri dalam cerita sangat dominan karena Fahri merupakan tokoh utama $A A C$. Ketokohutamaan Fahri sesuai dengan kriteria yang dinyatakan oleh Sayuti (2000:74) men- 
genai tokoh utama atau tokoh sentral, yaitu sebagai berikut.

Biasanya tokoh sentral merupakan tokoh yang mengambil bagian terbesar dalam peristiwa dalam cerita. Peristiwa atau kejadian-kejadian itu menyebabkan terjadinya perubahan sikap dalam diri tokoh dan perubahan pandangan kita sebagai pembaca terhadap tokoh tersebut. Jelasnya, tokoh utama atau tokoh sentral suatu fiksi dapat ditentukan, paling tidak dengan tiga cara. Pertama, tokoh itu yang paling terlibat dengan makna atau tema. Kedua, tokoh itu paling banyak berhubungan dengan tokoh lain. Ketiga, tokoh itu yang paling banyak memerlukan waktu penceritaan

Berkaitan dengan ketokohutamaan Fahri, salah satu pembaca dalam situs http://moniknurulafiah.multiply. com/journal/item/14/menyatakanbahwa pada setengah cerita, permasalahan sengaja dimunculkan untuk memberikan pesan bahwa plot sebelumnya belum bisa membuat Fahri menjadi tokoh yang kuat. Permasalahan seperti penokohan tokoh Aisha yang ingin mengambil jatah kekuasaan cerita dengan ditokohkan menjadi seorang yang kaya raya, tak bisa menggoyahkan pegangan Fahri atas semua alur yang telah dibangun pengarang. Fahri tetap menjadi tokoh sentral yang kuat, memegang peranan dalam cerita. Aisha mengalah dan mundur. Begitupun dengan klimaks yang terjadi yaitu ketika Fahri harus dijebloskan ke penjara, disiksa dengan sangat keras, terpisahkan dari sumber kekuatannya, yaitu tokoh Aisha, tetapi Fahri tetap keluar sebagai tokoh kuat yang mengatur jalannya plot cerita. Dari kesemua usaha penokohan yang dibangun, Fahri tetap menjadi tokoh sentral yang menguasai seluruh cerita.
Untuk Tokoh Fahri yang dicitrakan sebagai lelaki "sempurna", pembaca cenderung meresepsi secara positif. Dari 93 resepsi pembaca terhadap tokoh Fahri, 56 pernyataan pembaca yang bernada positif dan 28 bernada negatif. Pembaca meresepsi tokoh Fahri secara positif menyatakan sosok Fahri ganteng, Islami, toleran, dan memunyai kepedulian sosial yang tinggi. Kegantengan Fahri disimilekan dengan bintang film Hongkong sehingga konkretisasi pembaca terhadap Fahri adalah Jackie Chan atau Jet Li.Oleh karena itu, pembaca menyatakan Fahri bermuka bersih (plontos) tanpa jambang, kumis, dan jenggot, namun Fahri islami. Fahri toleran terhadap sesama muslim maupun nonmuslim. Fahri toleran dan tetap menjalin hubungan sosial terhadap Maria dan keluarga Maria meskipun mereka bukan muslim. Perhatian Fahri juga dinyatakan dengan memberi kado pada keluarga Maria ketika ada yang ulang tahun. Sikap Fahri yang demikian menyebabkan pergaulan Fahri tidak terhambat karena perbedaan agama, bahkan Maria dan keluarga simpati terhadap Fahri. Tampaknya Fahri dicitrakan juga sebagai pengejawantahan Islam yang menjadi rahmat untuk semesta alam. Kepedulian sosial Fahri yang lainya adalah kepedulian Fahri terhadap Noura. Fahri berani mengambil risiko dengan menitipkan Noura pada Maria dan Nurul untuk menghindarkan Noura dari perlakuan kasar orang tuanya. Noura sering menerima siksaan fisik dan psikis, bahkan Noura akan dijual kepada lelaki hidung belang. Risiko yang mungkin diterima Fahri adalah Fahri bisa berhadapan dengan Bahadur, bapak Noura, yang memunyai tabiat preman yang bringas. Mengungsikan Noura dan kemungkinan berhadapan dengan Bahadur merupakan resiko yang amat berat karena Fahri adalah orang asing (pendatang) di Mesir. 
Pembaca yang meresepsi secara negatif menyatakan sosok Fahri terlalu sempurna, tidak membumi, Fahri seperti malaikat. Dalam konteks ini pembaca mengaitkan pengetahuan pembaca berkaitan dengan kehidupan nyata, yaitu sulit mencari sosok seperti Fahri. Pembaca menyatakan karakter tokoh utama, Fahri, terlalu diidealisasikan secara berlebihan. Ia begitu suci tanpa cacat, seperti malaikat. Jika itu dimaksudkan sebagai teladan, pembaca tidak yakin ada manusia zaman sekarang yang mampu menirunya. Kesucian Fahri terasa naif, bahkan kejam. Misalnya, saat Maria sakit dan pingsan, Fahri tetap bersikukuh tidak mau menyentuhnya, padahal itulah satu-satunya cara agar Maria bisa siuman. Pembaca juga menyatakan keraguannya, apakah keteguhan Fahri yang dilandasi syariat itu patut mendapat pujian?

Ada juga pembaca yang meresepsi secara negatif terkait dengan kenyataan bahwa Fahri merasa minder untuk menyatakan cinta kepada Nurul karena Nurul anak seorang kyai kondang di Jawa Timur, sedangkan Fahri anak seorang petani dan penjual tape. Keminderan/rasa rendah diri ini mengherankan pembaca karena tokoh sekaliber Fahri begitu rendah menilai diri sendiri. Dengan ilmu dan sifat sehebat itu Fahri seharusnya tidak merasa minder untuk menyatakan cinta meskipun dia berasal dari keluarga miskin dan berasal dari desa. Memang kenyataan Fahri yang demikian terasa aneh karena Fahri telah dicitrakan sebagai orang yang ganteng, berpengetahuan luas, bertakwa, dan idealnya Fahri juga tahu bahwa yang membedakan manusia di hadapan Allah adalah derajat ketakwaannya. Oleh karena itu, seharusnya Fahri memunyai keberanian untuk menyatakan cinta, baik langsung maupun tidak langsung.
Jika Fahri merupakan tokoh utama, tiga tokoh yang lain (Aisha, Maria, dan Nurul) merupakan tokoh tambahan. Berkaitan dengan tokoh Aisha, pembaca meresepsi bahwa Aisha, 25 tahun, adalah perempuan yang cantik. Kecantikan Aisha tersebut dikaitkan dengan dimensi sosiologis Aisha yang berdarah campuran Jerman-Turki-Palestina. Aisha sebagai gadis peranakan Jerman-Turki-Palestina dilukiskan cantik bagai bidadari. Namun, pembaca tidak secara spesifik mengonkretkan kecantikan Aisha.

Pembaca juga menyatakan Aisha adalah alumni S1 Psikologi di Jerman. Resepsi pembaca tersebut tampaknya tidak sesuai dengan keterangan yang dari $A A C$ karena sesungguhnya Aisha belum menyelesaikan kuliahnya. Setelah menjadi istri Fahri, mereka masih merencanakan untuk segera menyelesaikan S1-nya. Aisha juga kaya raya karena mendapatkan warisan dari orang tuanya. Bahkan, Fahri menyebutkan Aisha termasuk golongan jet set. Meskipun kaya raya, Aisha tidak memandang orang lain dari hartanya. Hal ini terbukti dengan dipilihnya Fahri sebagai suami. Pertimbangan Aisha adalah ketakwaan Fahri sehingga ia akan mendapatkan kebahagian dunia dan akhirat.

Selain Fahri dan Aisha, Maria juga tokoh yang diresepsi oleh pembaca. Maria bernama lengkap Maria Girgis. Maria bergama Kristen Koptik. Maria jatuh cinta pada Islam. Maria begitu apresiatif dan positif dalam menandang Islam. Representasi Islam dalam $A A C$ terwujud pada sosok tokoh Fahri. Menurut pembaca, Maria yang bersemangat mencari kebenaran dan akhirnya masuk Islam karena melihat keagungan Islam pada diri Fahri. Terkait dengan hidayah yang diterima Maria, salah seorang pembaca menyatakan setelah membaca $A A C$, pembaca terpaku mencermati sosok tokoh Maria. Hal itu disebabkan 
Maria yang seorang Kristen Koptik saja bisa bersifat demikian terhadap Islam sehingga dia bisa menemukan surga di pintu Babur Rahmah. Resepsi pembaca ini terkait dengan peristiwa pada bagian akhir $A A C$ yang menceritakan kondisi Maria yang sakit dan tidak sadarkan diri sampai Maria meninggal dunia.

Adegan Maria berwudlu, membaca sahadat, dan masuk Islam merupakan adegan yang merepresentasikan puncak misi dakwah dalam $A A C$. Misi dakwah sangat terasa dalam $A A C$ karena melalui unsur fiksional pengarang melekatkan nilai-nilai Islam. Pengarang memunyai misi tersebut merupakan hal yang wajar karena pengarang sebagai manusia memang makhluk ideologis; ada hal-hal yang mendasari tindakannya dan hal-hal yang diperjuangkannya. Mengenai misi dalam berkarya, seorang penyair, cerpenis, dan redaktur harian Republika, yaitu Ahmadun Yosi Herfanda menyatakan sebagai berikut.

Dengan demikian, gaya cerpen-cerpen dalam buku ini memang cukup beragam, sejak realis sampai surealis, namun tetap dalam semangat humanisme-religius. Semangat itu tidak terlepas dari motivasi saya dalam menulis, yakni sebagai ibadah, sekaligus ijtihad dan jihad bil qalam. Dalam hal ini, saya percaya pada kata-kata Al-Ghazali bahwa pena seorang cendikia (pengarang) lebih berharga daripada tetesan darah seorang syuhada (Herfanda, 2004:x-xi)

Berkaitan dengan misi dakwah tersebut, termasuk pindahnya Maria ke agama Islam, juga diresepsi secara berbeda oleh pembaca. Salah seorang pembaca melihat bukan tentang romantisme cinta yang menjadi tujuan penulis $A A C$. Namun, tujuan yang diharapkan adalah melecehkan umat kristiani. Penulis terlalu tendensi radikalisme Islamnya; tanpa menghiraukan tanggapan umat kristiani. Lebih lanjut, pembaca menyatakan bagi pembaca yang mengedapankan kerukunan antarumat beragama, $A A C$ bukanlah novel yang tepat untuk dibaca. Penulis hanya menciptakan gesekan umat beragama. Dengan tegas dinyatakan tolak $A A C$; sekali lagi saya ajak semua untuk serentak berteriak tolak-tolak $A A C$. Resepsi yang berbeda justru datang dari pembaca yang mengaku nonmuslim. Pembaca memahami dan mau mengerti bahwa $A A C$ merupakan novel dakwah untuk agama Islam. Oleh karena itu, jika $A A C$ bertendensi menyebarkan ajaran Islam dan mengajak orang untuk memeluk agama Islam, merupakan hal yang wajar. Kemudian pembaca menyatakan bahwa dia juga berdakwah, yaitu mendakwahkan ideidenya. Tampaknya pembaca hendak menyatakan kalau sesuatu dilabeli bahwa sesuatu itu bermisi dakwah, maka pembaca selayaknya tidak mudah tersinggung. Hal itu tentu berkaitan dengan pertanyaan, apa tujuan akhir dari dakwah kepada orang yang tidak seagama dengan pendakwah?

Mengenai tokoh Nurul, pembaca menyatakan Nurul adalah anak seorang kyai terkenal (besar) di Jawa Timur. Ayah Nurul bernama K.H. Ja'far Abdur Razaq. Seperti halnya Fahri, Nurul juga sedang menuntut ilmu di Al Azhar. Menurut pembaca, Nurul adalah gadis yang manis dan beraura menenangkan. Memahami dan mengonkretkan manis tersebut sangat sulit karena makna yang dikandung kata manis yang dikaitkan dengan seorang gadis sangat subjektif dan banyak menimbulkan asosiasi. Manis bisa berkaitan dengan raut muka, kulit, senyum, gigi, tutur kata, dan lain-lain. Begitu juga asosiai yang ditimbulkan dengan kata menenangkan. Salah satu yang bisa ditafsirkan adalah pembaca menerima Nurul sebagai gadis yang keibuan. Keibuan juga berasosiasi dengan seorang wanita yang bisa 
dijadikan tempat berkeluh kesah dan meminta perlindungan. Resepsi pembaca ini kemungkinan terkait dengan kerelaan Nurul untuk menerima Noura saat Noura mengalami penyiksaan oleh keluarganya. Asosiasi yang bisa melebar ke mana-mana tersebut sesuai dengan yang dinyatakan oleh Saussure (dalam Widada, 2009:21), yaitu sebuah tanda, kata atau istilah, yang digunakan dalam satu tindak berbahasa seolaholah muncul sebagai pusat konstelasi, yakni sebuah titik tempat tanda-tanda lain berkonvergensi dan berkoordinasi melalui penalaran tertentu. Hubungan asosiatif tersebut dinamakan hubungan paradigmatik.

Pembaca meresepsi Nurul sebagai orang yang cerdas dan percaya diri. Kecerdasan tersebut terkait dengan intelektualisan Nurul sebagai mahasiswa Al Azhar dan juga diwujudkan dengan kemampuanya untuk memimpin suatu organisasi yang beranggotakan para mahasiswi. Kepercayadirian $\mathrm{Nu}-$ rul berkaitan dengan keberaniaannya dalam menyatakan cintanya kepada Fahri meskipun tidak secara langsung (melalui perantara sang paman). Namun, pembaca yang lain menyatakan hal yang berbeda, yaitu dengan menyatakan bahwa Nurul sebagai wanita Jawa sering memilih memendam perasaannya. Jika dicermati dalam $A A C$, Nurul memang memendam perasaan cintanya kepada Fahri. Memendam perasaan dan menyatakan cinta secara tidak langsung tersebut juga dapat ditafsirkan bahwa Nurul menjaga adab pergaulan. Dengan demikian, dua tanggapan pembaca tersebut sebenarnya tidak bertentangan ketika ditafsirkan dalam konteksnya.

\section{Bagan Tahapan Alur}

Tokoh-tokoh dalam AAC mengalami peristiwa dan berinteraksi melalui tahapan-tahapan tertentu sehingga bisa terjalin menjadi satu kesatuan cerita.
Jalinan peristiwa tersebut dinamakan alur. Selain Alur sebagai salah satu unsur $A A C$ juga menjadi perhatian pembaca. Alur merupakan tahapan-tahapan peristiwa yang dialami tokoh yang terjalin menjadi suatu cerita (Abrams, 1981:137). Suroto (1990:89) menyatakan alur atau plot ialah jalan cerita yang berupa peristiwa-peristiwa yang disusun satu persatu dan saling berkaitan menurut hukum sebab akibat dari awal sampai akhir cerita. Sayuti (2000:31) menegaskan plot atau alur fiksi hendaknya diartikan tidak hanya sebagai peristiwaperistiwa yang diceritakan dengan panjang lebar, tetapi juga merupakan penyusunan yang dilakukan oleh penulisnya mengenai peristiwa-peristiwa tersebut berdasarkan hubungan kausalitasnya. Gustav Freytag menggambarkan alur dengan sebagai $\mathrm{V}$ terbalik, yaitu seperti pada gambar berikut ini.

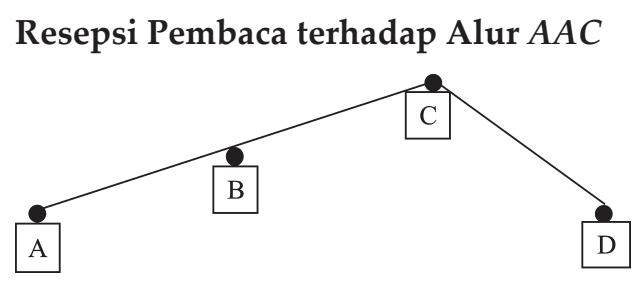

Keterangannya adalah AB menggambarkan eksposisi, B pengantar konflik, BC kenaikan aksi, komplikasi atau perkembangan konflik, $C$ klimaks atau peralihan aksi, dan CD penyelesaian atau pemecahan konflik (Sugihastuti, 2007:36). Mengenai tahapan alur, Esten (1987:26) menyatakan biasanya alur cerita rekaan terdiri dari (1) situasi, mulai melukiskan keadaan; (2) generating circumstances, peristiwa-peristiwa mulai bergerak; (3) rising action, keadaan mulai memuncak, (4) klimaks, mencapai titik puncak; dan (5) denouement, pemecahan soal atau peleraian.

Jika tahapan alur tersebut dikaitkan dengan $A A C, A A C$ menggunakan pengembangan alur sesuai dengan 
tahapan tersebut. Dengan kata lain, $A A C$ menggunakan alur maju atau alur lurus. Penggunaan alur maju $A A C$ ini pun mendapat resepsi secara positif. Alur $A A C$ mengalir lancar dan rapi dengan diwarnai penggambaran situasi seperlunya sehingga jalan cerita mudah diikuti dan mudah dipahami. Bagian awal cerita yang menggambarkan situasi dan kondisi kota Cairo yang panas merupakan dasar cerita yang menarik pembaca. Dari sinilah cerita bergulir, yaitu meskipun cuaca sangat panas, Fahri tetap keluar rumah untuk pergi mengaji. Namun, pembaca yang meresepsi secara negatif justru menyatakan bagian awal cerita lambat dan berteletele. Untuk sebuah perjalanan mengaji saja, diperlukan deskripsi hingga 50 halaman. Pembaca juga meresepsi bahwa alur $A A C$ datar karena hampir tanpa konflik yang berarti seperti membaca catatan harian. Ada juga pembaca yang meresepsi negatif pada bagian awal, namun meresepsi secara positif pada bagian yang lain.

Membaca Novel Ayat-Ayat Cinta, membuat saya mengantuk hingga setengah buku. Kantuk itu hilang pada saat bab mulai mengarah ke konflik. Yaitu ketika Fahri difitnah, masuk penjara dengan vonis mati, lalu seorang gadis kristen koptik bernama Maria datang menyelamatkan dengan 'syarat' kalau dia harus dinikahi dulu. Padahal Fahri saat itu sudah beristeri seorang gadis TurkiJerman, Kaya dan cantik bernama Aisha. Kenapa mendadak saya tidak mengantuk? Buat saya disitulah letak religiusnya. Buat saya, religius bukan semata-mata mulut berucap doa dan puja-puji kepada Tuhan; religius juga bukan aktifitas menyeru tentang kebaikan di atas mimbar, di TV, Radio atau majalah sambil berdendang asik dengan ayat-ayat Quran dan Hadist. Bagi saya, religius adalah ketika manusia berada dalam kesadaran penuh atas ketidaksempurnaan. Ketidaksempurnaan itu membuat manusia merasa dirinya tolol, merunduk, bersujud dan ... bertawaqal. Saya merasa pada saat itu Fahri menjadi tokoh yang sangat saya cintai (data 230).

Mengenai akhir dari $A A C$, pembaca menyatakan hal yang membuat novel ini disebut novel romantis adalah kisah-kisah menjelang dan pascapernikahan Fahri dan Aisha. Keromantisan tersebut berkaitan dengan masa indah dan masa sulit yang dialami para tokoh dan berakhir dengan happy ending, yaitu dengan dibebaskannya Fahri dari tuduhan memerkosa. Ditinjau dari sisi Maria, happy ending karena Maria dan Fahri bisa menyatu menjadi suami istri dan Maria meninggal dengan indikasi masuk surga. Oleh karena itu, keromantisan dan kebahagiaan tersebut tidak terlepas dari nuansa cinta yang sangat tinggi kepada Allah, melebihi rasa cinta antarmanusia.

Mengenai akhir cerita $A A C$, ada juga pembaca yang memandang aneh terkait dengan kematian Maria. Dengan menikahi Maria berarti Fahri berpoligami, namun dalam $A A C$ sama sekali tidak diceritakan suka dukanya poligami. Keanehan terjadi pada bagian tersebut. Maria yang sudah sembuh total dimatikan oleh pengarang. Kematian Maria mengusik logika pembaca karena ada sesuatu yang tidak logis. Berdasarkan kehadiran tokoh-tokoh, Fahri-Aisha-Maria-Noura, cuma Maria yang berhasil melewati masa krisis. Pascapernikahan, justru Fahri-Aisha-Noura yang dalam keadaan labil. Mereka mengalami puncak krisis. Fahri cemas tidak bisa menyatukan keutuhan istri-istrinya, terutama Aisha. Aisha dalam kondisi hamil tua memendam konflik batin menyaksikan kemesraan hubungan Fahri- 
Maria. Noura harus terus menelan pil pahit pasca diperkosa sang paman. Secara nalar logika, di antara ketiga orang inilah yang seharusnya mengalami puncak krisis sehingga berakibat kematian. Oleh karena itu, kondisi yang demikian mengesankan jalan cerita dipermudah dengan mematikan Maria. Berani memunculkan masalah, tetapi tidak berani menghadapi dan memberikan alternatif solusinya.

\section{Resepsi Pembaca terhadap Latar AAC}

Latar adalah segala keterangan mengenai waktu, ruang, dan suasana terjadinya lakuan dalam karya sastra (Sudjiman, 1984:46). Dalam konteks latar karya sastra Aminuddin (2009:67) menjelaskan peristiwa-peristiwa dalam cerita fiksi juga selalu dilatarbelakangi oleh tempat, waktu, maupun situasi tertentu. Budianta, dkk. (2008:86) menyatakan deskripsi latar dapat besifat fisik, realistis, dokumenter, dapat pula deskripsi perasaan. Dengan demikian, latar dapat dibedakan menjadi latar tempat, waktu, dan sosial. Reseps pembaca terhadap latar $A A C$ berkaitan dengan latar tempat dan sosial karena latar waktu tidak menjadi perhatian pembaca.

Banyak pembaca yang meresepsi latar $A A C$ secara positif. Salah satunya, pembaca merasa terjerat pada kehalusan penulis dalam memotret suasana alam Mesir. Kehidupan Mesir yang menjadi latar belakang cerita ini digambarkan dengan begitu mengesankan. Pembaca seakan merasakan langsung suasana Mesir dalam panas 41 derajat Celsius. Gambaran budaya masyarakatnya. Humor-humor segar yang digunakan dan banyak lagi. Hal tersebut membuat pembaca seakan-akan memasuki Mesir dengan detail kota yang menakjubkan. Deskripsi yang demikian merupakan kelebihan yang terdapat dalam $A A C$. Bahkan, pembaca menyatakan suasana kota Mesir yang menjadi setting utama dalam novel ini mampu digambarkan secara detail dan mendalam yang membuat pembaca merasa seolah-olah telah mengetahui Mesir dan bahkan merasa pernah tinggal dan menetap di Mesir.

Selain latar tempat, pembaca juga meresepsi latar sosial. Penggambaran latar sosial yang baik membuat pembaca merasa memperoleh informasi baru, yaitu mengenai kondisi dan perilaku penduduk mesir. Pembaca menemukan insipirasi baru tersebut ketika pembaca mencermati cara Fahri berinteraksi dengan penduduk lokal. Menurut pembaca, Penggambaran latar sosial budaya Mesir tersebut sangat hidup tanpa harus menggunakan kata-kata bahasa Arab.

Selain resepsi yang bernada positif, yaitu mengacu pada pernyataan pembaca bahwa $A A C$ bagus, ada juga pembaca yang meresepsi secara negatif latar $A A C$. Resepsi negatif ini terkait dengan adegan di dalam Metro. Pembaca menyatakan Mesir bukanlah negara yang menjadikan Islam sebagai dasar negaranya. Dengan demikian, Mesir bukanlah negara Islam. Karena dzimmi merupakan satu bentuk perjanjian, harus ada dua pihak yang mengikat perjanjian tersebut. Ketiadaan negara Islam mengakibatkan tidak adanya perjanjian dzimmi tersebut. Oleh karena itu, menjadikan turis sebagai dzimmi dalam novel tersebut merupakan hal yang tidak tepat.

Masih mengenai permasalahan turis tersebut, pembaca yang lain menanggapi bahwa kita jangan membuat kesimpulan yang salah. Kalau tidak dianggap sebagai ahlu dzimmah, apa turis tersebut layak dianiaya, dipukuli atau ditinju. Kesimpulan yang demikian merupakan kesimpulan yang sangat sempit. Memang pengambilan kesimpulan hukum yang menganggap turis sebagai ahlu dzimmah adalah keliru. Namun, sebagai sesama manusi kita tetap bisa berinteraksi dengan baik dengan mere- 
ka sepanjang mereka tidak menggangu akidah kita (bermuamalah biasa).

\section{SIMPULAN}

Berdasarkan pada teori, metodologi, dan temuan penelitian, berikut ini dikemukakan simpulan mengenai resepsi pembaca terhadap unsur fakta cerita dalam $A A C$. Resepsi terhadap fakta cerita meliputi resepsi pembaca terhadap tokoh cerita, alur cerita, dan latar cerita. Secara umum, fakta cerita lebih banyak diresepsi secara positif daripada negarif.

Tokoh cerita diresepsi oleh pembaca dan secara kuantitatif berurutan adalah Fahri, Aisha, Maria, dan Nurul. Mereka secara umum diresepsi secara positif dibandingkan dengan pembaca yang meresepsi secara negatif (80:30). Karena tokoh cerita merupakan sosok manusia yang hidup dalam dunia katakata, melalui imajinasi pembaca, sosok tersebut dapat dikonkretkan dengan cara mengaitkan kode-kode verbal dengan pengetahuan dan pemahaman pembaca. Fahri diimajinasikan sebagai sosok yang ganteng, dikonkretkan dengan menyepertikan Fahri seperti bintang film Hongkong, dan Fahri juga seorang laki-laki yang taat beragama. Tokoh Aisha dikonkretkan seperti bidadari karena berdarah campuran JermanTurki-Palestina, Aisha seorang gadis yang kaya raya, dan memunyai kepribadian yang baik. Tokoh Maria lebih banyak diresepsi mengenai ketertarikannya terhadap Islam dan masuknya dalam Islam. Untuk Nurul, pembaca menyatakan Nurul anak kiyai besar di Jawa Timur. Ia bersuku Jawa, berusia 26 tahun, manis, cerdas, percaya diri, dan santun.

Pembaca lebih banyak meresepsi alur secara positif, namun yang meresepsi alur secara negatif juga banyak (32:25). Pembaca meresepsi alur, baik alur secara utuh maupun bagian dari alur (terutama bagian awal dan akhir).

Secara umum pembaca meresepsi latar secara positif dibandingkan dengan pembaca yang meresepsi secara negatif (35:4). Latar cerita yang diresepsi pembaca adalah latar tempat dan latar sosial. Penggambaran latar tempat, Mesir, yang panas menarik perhatian pembaca sehingga melalui kode-kode verbal yang dirangkai oleh pengarang, pembaca seakan-akan dapat merasakan situasi dan kondisi Mesir yang panas. Latar sosial yang menarik perhatian pembaca adalah berkaitan dengan penyikapan terhadap turis asing yang berada di Mesir.

\section{UCAPAN TERIMA KASIH}

\section{DAFTAR PUSTAKA}

Abrams, M.H. 1981. A Glossary of Literary Terms. New York: Holt, Rinehart and Winston.

Al-Fayyadl, M. Derrida. Yogyakarta: LKis.

Amiduddin. 2002. "Pendekatan Pascastruktural: Jacques Derrida". Analisis Wacana dari Linguistik sampai Dekontruksi (Editor Kris Budiman). Yogyakarta: Kanal.

Aminuddin. 2009. Pengantar Apresiasi Karya Sastra. Bandung: Sinar Baru Algensindo.

Budianta, M.; Husen, I.S.; Budiman, M.; Wahyidu, I. 2008. Membaca Sastra Pengantar Memahami Sastra untuk Perguruan Tinggi. Jogya: IndonesiaTera.

El Shirazy, H. 2008. Ayat Ayat Cinta. Jakarta: Republika.

Esten, M. 1989. Kesusastraan Pengantar Teori dan Sejarah. Bandung: Angkasa.

Herfanda, A. Y. 2004. Badai Laut Biru. Jakarta Selatan: Senayan Abadi Publishing. 
Holub, R.C. 1984. Reception Theory. New York: Metheun, Inc.

Ibrahim, A. S. 2007. Teori-teori Pengetahuan Modul Pengayaan Matakuliah Filsafat Ilmu Bahasa. Malang: Tidak Diterbitkan.

Iser, W. 1987. The Act of Reading. London: The Johns Hopkins Press Ltd.

Malna, A. 2000. Sesuatu Indonesia. Yogyakarta: Yayasan Bentang Budaya.

Nurgiyantoro, B. 1995. Teori Pengkajian Fiksi. Yogyakarta: Gadjah Mada University Press.

Ratna, N. K. 2007. Estetika Sastra dan Budaya. Yogyakarta: Pustaka Pelajar.

Ratna, N. K. 2007. Stilistika Kajian Puitika Budaya, Sastra, dan Budaya. Yogyakarta: Pustaka Pelajar.

Ricoeur, P. 1981. Hermeneutika Ilmu Sosial. Terjemahan oleh Muhammad Syukri. 2005. Yogyakarta: Kreasi Wacana.
Ricoeur, P. 1999. A Ricoeur Reader: Reflection and Imagination (Valdes, Ed.). Canada: HarversterWheatsheaf.

Rosenblatt, L. M. 1978. The Reader, the Text, the Poem. USA: Southern Illinois University Press.

Sartre, J.P. 1967. Word Menguak Kekuatan Menulis dan Membaca. Terjemahan oleh R. Melinda. 2009. Surabaya: Selasar.

Sayuti, S. A. 2000. Berkenalan dengan Prosa Fiksi. Yogyakarta: Gama Media.

Stanton, R. 1965. Teori Fiksi. Terjemahan oleh Sugihastuti dan Rossi Abi Al Irsyad. 2007. Yogyakarta: Pustaka Pelajar.

Sudjiman, P. 1984. Kamus Istilah Sastra. Jakarta: Gramedia.

Suroto. 1990. Apresiasi Sastra Indonesia untuk SMA. Jakarta: Erlangga.

Widada, Rh. 2009. Saussure untuk Sastra Sebuah Metode Kritik Sastra Struktural. Yogyakarta: Jalasutra. 